\title{
Exploring Undergraduate Students' Motivation-regulation Strategies in Thesis Writing
}

\author{
Krismalita Sekar Diasti \\ Universitas Sanata Dharma, Indonesia \\ Email: krismalita.sekar@gmail.com \\ Concilianus Laos Mbato \\ Universitas Sanata Dharma, Indonesia \\ Email:cons@usd.ac.id
}

\begin{abstract}
Self-regulation is an ability that helps the students to maintain their effort in achieving their goals. In self-regulation, students can plan, monitor, and evaluate their learning process. Self-regulation encompasses many aspects. One of them is motivation. Motivation is considered as one of the important aspects of the learning process. Concerning the educational context in Indonesia, thesis writing course is a compulsory course. However, students are required to do the task independently. Therefore, students have to be self-regulated learners during the process of thesis writing. This study aims to investigate students' motivation-regulation strategies in thesis writing. There were 9 participants involved in this study. The participants were students of English Language and Education Study Program of Sanata Dharma University. This study belongs to mixed-method research. Questionnaire and interview were used as instruments to collect the data. The results of this study revealed that the participants used some motivation-regulation strategies, namely, self-consequating, environmental structuring, goal-oriented self-talk, interest enhancement, and attribution control. Additionally, the majority of the participants were apt to procrastinate writing their thesis. The implications are provided for undergraduate students, thesis advisor, and future researchers.
\end{abstract}

Keywords: self-regulation, motivation-regulation, motivation-regulation strategies

\section{INTRODUCTION}

With regard to educational context in Indonesia, writing a thesis is a compulsory course which students should pass to graduate from a university. Students who graduate on time are considered successes in attaining their bachelor's degree (Amin, Indahwati \& Angraini, 2013). Students who graduate on time are those who finish their studies less or exactly four years (Amin et al., 2013). On the other hand, students who graduate not on time are those who graduate for more than five years (Amin et al., 2013). To guarantee the quality of a university, every university continuously monitors and evaluates the quality of graduates especially the stipulated time for graduating.

In English Language Education Study Program, henceforth called ELESP, of Sanata Dharma University, students must write a thesis or research paper as a requirement to graduate. Many students can finish writing their thesis on time while others need more than four years to finish it. There are several factors influence the students in writing their thesis. One of the fac- tors is motivation. Motivation is an important factor that determines students' successfulness as motivation will keep students on the right track to achieve their goals (Ellis, 1994; McDonough, 1983; Mali, 2015). Although the goal has already been determined by the university, motivation still holds an important role to engage the students in achieving the directed goal.

Many students do not finish writing their thesis on time because they are unmotivated to write it. Factors that can affect students to become unmotivated come from internal and external. Internal factors can be a willingness to finish writing thesis as soon as possible, curiosity to explore more about the topic since the topic is interesting for the students and thought that writing thesis will be beneficial for their future. Motivation that comes from external can be support from parents, friends, and lecturers. Both internal and external factors can support the students to finish writing their thesis.

In thesis writing course, students are required to finish the process individually. The lecturer is only the facilitator and not the main determinant for the students to graduate on time. 
Therefore, students should have the capability to regulate their learning. Based on the theories of self-regulation, a person is successful in the learning process when he can monitor and evaluate his learning process independently (Oates, 2019). Students do not always have high motivation in writing their thesis. The low motivation for completing a task can be a hindrance in self-regulated learning (Grunschel, Schwinger, Steinmayr \& Fries, 2016). Therefore, students need to increase or maintain their motivation to attain the goal.

Motivation plays a crucial aspect in the learning process (Rofi, Rukmini, \& Hartono, 2014; Budiana \& Djuwari, 2018). Motivation is believed as one of the paramount factors in attaining a goal. In a classroom, students are diverse and have different differences. The differences can be seen from their motivation as well (Apriliyanti, Warsono, \& Mujiyanto, 2018).

Syafiq and Saleh (2012) claim that motivation is an important factor which can influence students' success or failure. According to Long, Min, and Chen (2013), motivation is a drive which directs into the goal. In line with Gilakjani, Leong, and Sabouri (2012) who claim that "motivation is the impulse that generates the action." Defina and Sundari (2016) also share the same point of view that motivation is something which direct and maintain students' behavior. In brief, motivation is a boost which emerges both from oneself and others.

There are two types of motivation, namely, intrinsic and extrinsic motivation. Intrinsic motivation is a form of motivation driven by pleasure, desire, attitude, interest, and the internal factors of an individual (Handriana, Ismail \& Mahdum, 2013). Extrinsic motivation can be found in praise, prizes, grades, and fun learning environment that encourage the students to learn (Handriana et al., 2013).

Motivation is one of the aspects in selfregulation (Mbato, 2013). Self-regulation is an ability which "individuals are metacognitively, motivationally and behaviorally active in their own learning" (Zimmerman, Bonner, \& Kovach, 1996). Metacognitively means that individuals are able to use their metacognition skills (plan, monitor and evaluate) in their learning process. Motivationally is when students have the desire to engage in the learning process. Behaviorally means that individuals show their efforts to achieve their goals. Zumbrunn, Tadlock, and Roberts (2011) share the same point of view that "self-regulation can assist the students in managing their thoughts, behaviors, and emotions in order to successfully navigate their learning expe- riences." Students who are self-regulated will be more successful in their achievements (Hallberg \& Olsson, 2017).

Self-regulation encompasses many aspects. For instance, motivation, attitude, volition, feelings, atribution, learned helplessnes and self-efficacy (Mbato, 2013). This study focuses on motivation-regulation. Motivation-regulation centralizes on activities to initiate or maintain students' willingness to accomplish a task (Wolters, 2003a). Motivation-regulation can also be addressed as regulation of motivation.

Regulating motivation is important as it can maintain or even increase the students' motivation (Grunschel et al., 2016). As Wolters and Benzon (2013) state that motivation-regulation can be defined as students' active participation in maintaining or improving their motivation. Dornei (2005) also defines that regulation of motivation is the way how we manage our motivation. It is believed that if a student can preserve their motivation, $\mathrm{h} / \mathrm{she}$ can learn better and accomplish a task successfully (Mukti, 2017). It can be concluded that motivation-regulation includes the behavior to maintain students' effort and persistence in completing a task.

Students need to be self-regulated learners in managing their motivation. It is found that students who use some motivation-regulation strategies will have an increasing effort management (Schwinger, Steinmayr, \& Spinath, 2009). The researcher focuses more on the regulation of motivation strategies stated by Wolters (2003a) although all the strategies are not included in this study. There are six strategies used as theoretical bases. The first strategy is self-consequating. This strategy is used when students give rewards to themselves after finishing the task. For instance, they will treat themselves with a delicious meal or go to the cinema. On the other hand, students will give themselves consequences when they have not finished doing the task in the target time.

The second strategy is environmental structuring. In this strategy, the students attempt to construct their surroundings as a comfortable place for them to do the task. Environmental structuring includes efforts to avoid destructions occurred in completing the task. For instance, students will choose a quiet room to study, listen to music while doing the task or even scold people who bother them. The third strategy is goal-oriented self-talk. Goal-oriented self-talk is students' thought which underlies why they should finish doing the task.

The fourth strategy is interest enhance- 
ment. Interest enhancement is a strategy used to increase students' intrinsic motivation such as making the learning process more enjoyable or interesting (e.g. through game). The fifth strategy is self-handicapping. Students elude obstacles that occurred before or during completing the task. For instance, the students avoid procrastinate the task or cram the night before the test. The sixth strategy is attribution control. This strategy is used when the students intentionally select factors which cause them to be succeeded or fail in completing a task. Attribution control can maintain, increase or even decrease students' motivation in doing a task.

Self-regulation is the most discussed topic by the previous researchers. Nevertheless, little research has discussed self-regulation in thesis writing course, especially in motivation (Mbato \& Cendra, 2019). According to Mbato and Cendra (2019), motivation-regulation is a paramount aspect for students in thesis writing course as it helps the students to maintain their motivation as well as assist them to find help when it is needed. This topic is relevant to the educational context in Indonesia as writing a thesis is a requirement for the students to graduate. To fill the gap, the researcher conducts this study focusing on motivation-regulation strategies. This study aims to examine students' motivation-regulation strategies in thesis writing course. The recommendations for students, thesis advisors, and future researchers are provided as well in this study.

\section{METHODOLOGY}

The researcher employed mixed method to collect and analyze the data. Mixed method is an approach that collects, analyzes, and mixes both quantitative and qualitative data in a single study (Creswell, 2012). There were nine participants involved in this study. Two out of nine participants were those who finished writing their thesis intime whereas, the others were those who have not done writing their thesis.

The participants were ELESP students batch 2014. The samples were chosen by using purposive sampling. Purposive sampling allows the researcher to find participants who are willing to give information related to the study (Mulyana, 2018). The considerations were that students who were graduated in-time, students in the eleventh semenster who took a thesis course and students who were willing to be the participant of this study.

Triangulation was used to crosscheck the data through different instruments. The instru- ments employed in this research were questionnaire and interview. The researcher calculated the data from questionnaire and found the mean of them. The results of the questionnaire were presented in the table. Then, the researcher interpreted the data and supported with the data from interview session.

\section{RESULTS AND DISCUSSION}

In this subchapter, the researcher elaborates on the findings obtained through questionnaire and interview. This subchapter is divided into six parts based on motivation-regulation strategies.

\section{Self-consequating}

Self-consequating strategy is used to provide an extrinsic reward or consequence for students' commitment in accomplishing a task (Zimmerman \& Pons, 1986; Wolters, Pintrich \& Karabenick, 2005). For instance, a student will treat himself a delicious meal after completing a task. Besides, the students can give themselves a consequence if they do not make any progress or do not accomplish a task.

The results of the questionnaire reveal that most of the participants give reward or consequence in the process of writing their thesis. The rewards and consequences are diverse. The findings of open-ended question show that the participants treat themselves to buy an ice cream, go to the salon, watch videos on YouTube, or travel around if they have significant progress in writing their thesis. However, some of them do not play their smart phones or hang out with their friends as the consequences of not completing their target.

Based on the result of the interviews, P9 states, "Kalau aku ada progres aku bakal pergi ke salon buat refresh pikiraku supaya bisa semangat lagi pas nglanjutin nulis skripsi (If there is a progress, I will go to salon to refresh my mind so I can be eager in to continue writing my thesis)." P1 also claims that "Ya paling beli es krim atau nonton film gitu kalo nggak ya main game biar enggak stress aja (I will buy an ice cream, watch a movie or play games just to make me feel less stress)." P2 share the same point of view as well. P2 states that "Aku suka ngasih reward dalam bentuk apapun misalnya aku bisa melakukan apapun yang ku mau kalau aku memenuhi targetku (I give reward to myself in any kind of form. For instance, I will allow myself to do anything if I can achieve my target)." These findings are supported by Grunschel et al., (2016) who 
Table 1. Students' self-consequating strategy

\begin{tabular}{lccccc}
\hline Statements & $\mathrm{SD}$ & $\mathrm{D}$ & $\mathrm{N}$ & $\mathrm{A}$ & $\mathrm{SA}$ \\
\hline $\begin{array}{l}\text { I promise myself I can do something that I want after com- } \\
\text { pleting my thesis chapters. }\end{array}$ & $(0)$ & $(0)$ & $(0)$ & $(6)$ & $(3)$ \\
$\begin{array}{l}\text { I give myself consequences when I have not made any prog- } \\
\text { ress in writing my thesis. }\end{array}$ & & & & $66.7 \%$ & $33.3 \%$ \\
& & $22.2 \%$ & $44.4 \%$ & $22.2 \%$ & $11.1 \%$ \\
\hline
\end{tabular}

Table 2. Students' environmental structuring strategy

\begin{tabular}{lccccc}
\hline Statements & $\mathrm{SD}$ & $\mathrm{D}$ & $\mathrm{N}$ & $\mathrm{A}$ & $\mathrm{SA}$ \\
\hline I prefer to write my thesis in a quiet room. & $(0)$ & $(0)$ & $(1)$ & $(4)$ & $(4)$ \\
& & & $11.1 \%$ & $44.4 \%$ & $44.4 \%$ \\
& $(1)$ & $(2)$ & $(1)$ & $(2)$ & $(3)$ \\
I like listening to music when I write my thesis. & $11.1 \%$ & $22.2 \%$ & $11.1 \%$ & $22.2 \%$ & $33.3 \%$ \\
& & & $22.2 \%$ & $33.3 \%$ & $44.4 \%$ \\
When writing my thesis, I try to make sure that I have a & $(0)$ & $(0)$ & $(2)$ & $(3)$ & $(4)$ \\
few destructions as possible. & & &
\end{tabular}

claim that the strategy of self-consequating will increase the chance of performing the same behavior again. The results of the interviews also present that the participants have timeline schedule in writing their thesis. However, they do not apply the timeline schedule. Therefore, the cannot achieve their target.

\section{Environmental structuring}

In completing a task, we tend to make our environment as comfortable as possible. Our effort to make the environment become comfortable can be defined as environmental structuring (Zimmerman \& Pons, 1986; Wolters et al., 2005). The actions to make the environment become pleasant can be done in various ways. For instance, listening to music when accomplish a task, choosing a quiet room to study, or scolding people who bother them. The results of the questionnaire reveal that the participants use several strategies to create a comfortable place to write their thesis.

Based on the Table 2, the participants prefer to write their thesis in a quiet room. Some of the participants listen to music while writing their thesis. In the interview session, P2 expresses that "Ya aku milih lingkungan yang sunyi sih, kalaupun enggak sunyi ya asal mereka enggak ngrecokin aku ya aku enggak masalah tapi kalau udah berisik banget ya aku tegur mereka (I prefer to choose a quiet environment, if it is not quiet as long as other people do not bother me then I do not mind about it but if they are too noisy then I will scold them)."

P3 conveys that "Tempatnya harus tenang supaya bisa fokus contohnya di perpustakaan walaupun banyak orang tapi tetap tenang. Kalau mengerjakan di kampus malah berisik (The place should be quiet so that I can be focus. For instance at the library. Although there are a lot of people the place is still quiet. If I do that at campus, it will be too noisy)." The findings from the interview session are in line with Grunschel et al., (2016) who emphasize that environmental structuring can be done by eliminating the distraction. Moreover, Wolters and Rosenthal (2000) claim that environmental structuring strategy is used to arrange students' environment which can support them to accomplish a task without interruption. It can be done by choosing a quiet room or ask other students to quiet down (Wolters et al., 2005).

\section{Goal-oriented self-talk}

To regulate motivation, students can affirm reasons why they would like to achieve a particular learning goal (Wolters et al., 2005). Students will highlight their important reason. In this motivation-regulation strategy, students will use their thoughts or verbal statement to foster their engagement in achieving a particular goal (Wolters et al., 2005). The findings reveal that the participants use this strategy to maintain their motivation. The participants use their thoughts to remind themselves that they should attain their goal.

The findings of the questionnaire show that most of the participants employ goaloriented self-talk strategy. The participants always remaind themselves to continue writing their thesis. Moreover, they also convince themselves about the importance of completing their thesis.

The findings from the interview session also indicate that the participants use this strategy in the process of writing their thesis. As Wolters (2003a) states that goal-oriented 
Table 3. Students' goal-oriented self-talk strategy

\begin{tabular}{lccccc}
\hline Statements & $\mathrm{SD}$ & $\mathrm{D}$ & $\mathrm{N}$ & $\mathrm{A}$ & $\mathrm{SA}$ \\
\hline When I want to give up, I convince myself to keep & $(0)$ & $(1)$ & $(3)$ & $(4)$ & $(1)$ \\
writing by thinking about completing my thesis. & & $11.1 \%$ & $33.3 \%$ & $44.4 \%$ & $11.1 \%$ \\
$\begin{array}{l}\text { I remind myself how important it is to finish writ- } \\
\text { ing my thesis. }\end{array}$ & $(0)$ & $(0)$ & $(3)$ & $(2)$ & $(4)$ \\
\hline
\end{tabular}

Table 4. Students' interest enhancement strategy

\begin{tabular}{lccccc}
\hline Statements & SD & D & N & A & SA \\
\hline I always try to make writing thesis as fun as possible. & $(0)$ & $(2)$ & $(4)$ & $(1)$ & $(2)$ \\
& & $22.2 \%$ & $44.4 \%$ & $11.1 \%$ & $22.2 \%$ \\
\hline
\end{tabular}

self-talk strategy is used to reinforce a certain behavior and keep persisting in achieving a particular goal. This statement is in line with the findings of the interview session. P1 mentions that "Eemmm, ya soalnya ini udah tahun keberapa jadi tidak boleh yang namanya nyerah, orang tua juga sudah mengoyak-oyak hehe $(\mathrm{Um}$, yeah because this is already the umpteen year so I cannot give up, my parents have already remind me as well)." P1 adds more information "Ya biasanya diingetin juga sih sama temen atau sama orang tua diingetin atau enggak liat di instagram foto-foto liburan wah enak ayok ndang hehe (My friends and parents always remind me or I got tempted by vacation photos on Instagram and I need to get rush)." P3 also shares the same idea "Pas aku lagi males biasanya orang tua mengingatkan jadi aku sadar dan harus segera menyelesaikan (When I am lazy to write my thesis, my parent reminds me and I realize that I should finish writing my thesis as soon as possible)."

\section{Interest Enhancement}

Students will intrinsically be motivated in attaining a learning goal if they are interested in certain activity (Wolters, 2003a). However, students will not always have high level of interest in something. Therefore, this strategy can be used to maintain and increace students' motivation in accomplishing a task. Based on the results of the questionnaire, some participants have interest in writing their thesis. Some other participants do not interested in writing their thesis.

Based on the results of the interviews, it can be concluded that the participants have interest in writing their thesis. They find that writing thesis is a fun activity to do. P1 mentions that "Ya biasanya sambil dengerin musik sih (I usually listen to music while writing my thesis)." As Wolters and Rosenthal (2000) claim that interest enhancement strategy can increase students' effort on completing a task by creating enjoyable situation. For instance, making learning into fun activity by creating a game (Grunschel et al., 2016).

However, they encounter some problems which can lower their interest. The results of the interviews are in line with the point of view shared by Hallberg and Olsson (2017) who emphasize that students will encounter some difficulties in writing an academic paper. P1 states that "Menyenangkan sebenernya hehe cuma apa ya karena dosennya tidak mau memberi tahu kesalahannya di mana jadi ya males ngerjain juga (It is actually interesting but my advisor does not want to tell my mistake. Then, I feel lazy to complete writing my thesis)." P2 adds that "Menyenangkan sih karena kan aku tertarik sama topik yang aku teliti (It is actually fun because I am interested in the topic that I chose)." Additionally, P3 reveals that "Sebernernya ada interest tapi aku enggak biasa nyomot perkataan ahli jadi susahnya disitu (Actually, I have an interest but I cannot cite experts' opinion so that is the hardest part)."

\section{Self-handicapping}

Based on the results of the questionnaire, there are two participants who finished writing their thesis in-time tended not to procrastinate in completing their thesis. There are seven out of nine participants who have not done writing their thesis. The participants who have not done writing their thesis opt to procrastinate writing their thesis chapters. These findings are supported by Wolters (2003b) who underlines that "high levels of procrastination appear inconsistent with the behaviors typically attributed to self-regulated learners." It can be concluded that high level of procrastination correlates to low level of self-regulation.

All interviewees mention that they tend to 
Table 5. Students' self-handicapping strategy

\begin{tabular}{llllll}
\hline Statements & SD & D & N & A & SA \\
\hline I avoid procrastinating on writing my thesis chapters. & $(1)$ & $(2)$ & $(4)$ & $(0)$ & $(2)$ \\
& $11.1 \%$ & $22.2 \%$ & $44.4 \%$ & & $22.2 \%$ \\
\hline
\end{tabular}

Table 6. Students' attibution control strategy

\begin{tabular}{lccccc}
\hline Statements & $\mathrm{SD}$ & $\mathrm{D}$ & $\mathrm{N}$ & $\mathrm{A}$ & $\mathrm{SA}$ \\
\hline $\begin{array}{l}\text { I blame myself when I do not make any progress in com- } \\
\text { pleting my thesis chapters. }\end{array}$ & $(0)$ & $(0)$ & $(4)$ & $(2)$ & $(3)$ \\
$\begin{array}{l}\text { I attribute other people as the causes of my failure in } \\
\text { completing my thesis chapters. }\end{array}$ & & $44.4 \%$ & $22.2 \%$ & $33.3 \%$ \\
& $33.3 \%$ & $11.1 \%$ & $44.4 \%$ & $11.1 \%$ & $(0)$ \\
\hline
\end{tabular}

procrastinate on writing their thesis. They provide the reasons why they procrastinate as well. P1 states that "Ya pernah, karena males terus banyak revisi (Yes, I have. I am just lazy because of too much revision)." P2 mentions "Iya, aku hanya mengulangi patternnya emm jadi ngerjain terus habis-habisan diralat terus balik lagi (Yes, I just repeat the pattern um so I write and then get the revision and repeat the same activity again)."

P3 revelas that "Sering, alasan aku suka nunda skripsi ya karena aku kesulitan untuk bahas sendiri jadi aku butuh temen untuk kaya diajak apa namanya katakanlah tuker pikiran dan sebagainya (I often put off writing my thesis. The reasons why I put off writing my thesis because I find difficulty so I need a friend to discuss and brainstorm and so on.)" The findings of this motivation-regulation strategy indicate that the participants do not use this motivation-regulation strategy. In line with Grunschel et al., (2016) who state that the more students use motivation-regulation strategies the lower will the procrastination on finishing the task be. However, the findings reveal that the students still procrastinate on completing their thesis. Procrastinate is the crucial aspect in completing a task since it can hinder the students in acomplishing a task. Therefore, students need to regulate themselves and avoid putting off the task.

\section{Attribution control}

Attribution is defined as a primary factor which can influence students' motivation (Sutantoputri \& Watt, 2012). Students can attribute something from external or internal factors as the causes of their success or failure. Students tend to attribute external factors such as other people or the task given when they encounter failure (Weiner, 1986).

Students need to address the causes appropriately. Appropriate attribution can be defined when students select the internal factors as the cause of their success or failure (Wolters, 2003).
This appropriate attribution refers to controllable factors which students can handle to overcome it. For instance, their effort in accomplising the task. In this motivation-regulation strategy, the participants have appropriate attribution control. They attribute themselves as the causes when they do not have progress in writing their thesis chapters.

The results of the interviews support the findings of the questionnaire as well. All the interviewees express the same idea. P1 claim that "Ya kalo aku enggak ada progress ya lebih nyalahin ke diriku sih (If I do not make any progres then I will blame myself)." P2 expresses "Emang bisa nyalahin siapa lagi hehe itu pasti salahku lah (Who else should I blame, of course that is my mistake)." P3 adds, "Condong menyalahkan diri sendiri sih karena kan kalo aku nunda ya pasti karena akunya males atau memang ada hal lain yang lebih penting buat aku kerjaiin (I tend to blame myself. I procrastinate writing my thesis mainly because I am lazy or I have another urgent thing which should be done quickly.)."

These findings are supported by Weiner (1986) who asserts that students should avoid blaming external factors for the causes of their success or failure. The findings of this motivationstrategy present that the participants have already attributed the causes of their failure or success appropriately. Students have to address appropriate attribution as attribution control plays an important role in sharpening students' motivation (Dornyei, 2005).

\section{CONCLUSION}

Research on students' motivation-regulation strategies has not been examined by the previous researchers. This topic is relevant in Indonesia educational context. Writing a thesis is one of the requirements for students to graduate from university level. This research has done to explore students' motivation-regulation strategies in thesis writing course. 
Motivation-regulation plays an important aspect in thesis writing course. Motivation-regulation is believed to help the students in mantaining and increasing their motivation to accomplish writing their thesis. This study focuses on motivation-regulation strategies used by undrgraduate students. Based on the findings, there are two conclusions elaborated in the following.

First, the participants only use five strategies of motivation-regulation, namely, self-consequating, environmental structuring, goal-oriented self-talk, interest enhancement, and attribution control. Second, most of the participant still procrastinated to write their thesis. The findings of this study are supported by previous studies (Wolters, 2003b \& Grunschel et al., 2016). Previous studies reveal that pocrastinating can affect students' motivation-regulation. Procrastination makes the students become unmotivated to continue writing their thesis.

In addition, the researcher provides three implications. First, students need to regulate themselves in writing their thesis. The deadline of thesis writing course is unclear. Therefore, each student has different timeline. Students have to be self-regulated, especially in maintaining their motivation. Students need to manitain or increase their motivation-regulation as it can drive them in achieving a certain goal. Second, the thesis advisor have to encourage the students. Encouragement from thesis advisor can boost students' motivation in completing their thesis writng task. Third, this study has a limitation. This research was conducted in a small sample size. Future researchers who are interested to examine similar area need to include a larger sample.

\section{REFERENCES}

Amin, F. N. A., Indahwati, \& Angraini, Y. (2013). Analisis ketepatan waktu lulus berdasarkan karakteristik mahasiswa fem dan faperta menggunakan metode chart. Xplore, 2(1), 1-8.

Budiana, K. M., \& Djuwari. (2018). The non-native students' motivation in learning English at STIE Perbanas Surabaya. Language Circle: Journal of Language and Literature, 12(2), 195-202.

Creswell, J. W. (2012). Educational research: Planning, conducting, and evaluating quantitative and qualitative research (4th ed.). Boston: Pearson Education Inc.

Defina, \& Sundari, H. (2016). Motivation in learning Indonesian as a foreign language for Korean students. Language Circle: Journal of Language and Literature, $\mathrm{X} / 2$.

Dornyei, Z. (2005). The psychology of language learners: Individual differences in second language acquisition. New Jersey: Lawrence Erlbaum Associ- ates, Inc., Publishers.

Ellis, R. (1994). The study of second language acquisition. Oxford: Oxford University Press.

Gilakjani, A. P., Leong, L. M., \& Sabouri, N. M. (2012). A study on the role of motivation in foreign language learning and teaching. I.J.Modern Education and Computer Science, 7, 9-16.

Grunschael, C., Schwinger, M., Steinmayr, R., \& Fries, S. (2016). Effect of using motivational regulation strategies on students' academic procrastination, academic performance, and well-being. Learning and Individual Differences, 49, 162-170.

Hallberg, D., \& Olsson, U. (2017). Self-regulated learning in students' thesis writing. Internation Journal of Teaching and Education, 5(1), 13-24.

Handriana, H., Ismail, M. A., \& Mahdum, M. (2013). The relationship between motivations and selflearning and the English language achievement in secondary high school students. Asian Social Science, 9(12), 36-43.

Long, C., Ming, Z., \& Chen, L. (2013). The study of student motivation on English learning in junior middle school: A case study of no. 5 middle school in Gejiu. English Language Teaching, 6(9), 136-145.

Mali, Y. C. (2015). Motivational factors in the Indonesian EFL writing classroom. Bahasa \& Sastra, 15(1), 1-11.

Mbato, C. L., \& Cendra, A. (2019). EFL undergraduate students' self-regulation in thesis writing: Help-seeking and motivation-regulation. Journal of English Language and Education, 5(1), 6682.

Mbato, C. L. (2013). Facilitating EFL learners' self-regulation in reading: Implementing a metacognitive approach in an Indonesian higher education context. ePublications@SCU. Southern Cross University.

McDonough, S. (1983). Psychology in foreign language teaching. London: George Allen \& Unwin.

Mulyana, D. (2018). Metodology penelitian kualitatif: Paradigma baru ilmu komunikasi dan ilmu sosial lainnya. Bandung: PT. Remaja Rosdakarya.

Mukti, T. W. P. (2017). The role of students' motivational self-regulation in structure III. Language and Language Teaching Journal, 20(2), 116-126.

Oates, S. (2019). The importance of autonomus, selfregulated learning in primary initial teaching training. Frontiers in Education, 4(102), 1-8.

Retno, A., Warsono, \& Mujiyanto, J. (2018). The correlation between interest, motivation, English self-concept and English speaking performance in nursing students. English Education Journal, $8(2), 138-147$.

Rofi, A., Rukmini, D., \& Hartono, R. (2014). Improving students' motivation in writing descriptive texts by using the mind mapping technique. English Education Journal, 4(2), 114-121.

Schwinger, M., Steinmayr, R., \& Spinath, B. (2009). How do motivational regulation strategies affect achievement: Mediated by effort management and moderated by intelligence. Learning 
and Individual Differences, 19, 621-627.

Susantoputri, N. W., \& Watt, H. M. G. (2012). Attribution and motivaiton: A cultural study among Indonesian university students. International Journal of Higher Education, 1(2), 118-129.

Syafiq, A. N., \& Saleh, M. (2012). Humor English teaching material for improving students' speaking skill with high and low learning motivation. Language Circle: Journal of Language and Literature, 7(1), 45-53.

Weiner, B. (1986). An attribution theory of motivation and emotion. New York: Springer-Verlag.

Wolters, C. A. (2003a). Regulation of motivation: Evaluating an underemphasized aspect of selfregulated learning. Educational Psychologist, $38(4), 189-205$.

Wolters, C. A. (2003b). Understanding procrastination from a self-regulated learning perspective. Journal of Educational Psychology, 95(1), 179-187.

Wolters, C. A., \& Benzon, M. B. (2013). Assessing and predicting college students' use of strategies for the self-regulation of motivation. The Journal of Experimental Education, 81(2), 199-221.

Wolters, C. A., Pintrich, P. R., \& Karabenick, S. A. (2005). Assessing academic self-regulated learning. Springer, 3, 1-49.

Woters, C. A., \& Rosenthal, H. (2000). The relation between students' motivational beliefs and their use of motivational regulation strategies. International Journal of Education Research, 33, 801820.

Zimmerman, B. J., Bonner, S., \& Kovach, R. (1996). Developing self-regulated learners beyond achievement to self-efficacy. Nebraska: American Psychological Association.

Zimmerman, B. J., \& Pons, M. M. (1986). Development of a structured interview for assessing student use of self-regulated learning strategies. American Educational Research Journal, 23(4), 614-628. 